\title{
Genetic diversity of pacu for restocking programs in the Tietê and Grande rivers, Brazil
}

\section{Diversidade genética de pacu utilizado em programas de repovoamento nos rios Tietê e Grande, Brasil}

\author{
Ricardo Pereira Ribeiro ${ }^{1}$; Nelson Mauricio Lopera-Barrero ${ }^{2 *}$; Silvio Carlos Alves \\ dos Santos; 3 Maria del Pilar Rodriguez-Rodriguez ${ }^{4}$; Sheila Nogueira de Oliveira ${ }^{5}$; \\ Luiz Alexandre Filho ${ }^{1}$; Lauro Vargas ${ }^{1}$; Elenice Souza dos Reis Goes ${ }^{6}$; \\ Pedro Luiz de Castro ${ }^{7}$; Angela Rocio Poveda-Parra ${ }^{8}$
}

\begin{abstract}
Piaractus mesopotamicus is a tropical fish under threat because of declines in the number of wild populations. Restocking programs have been developed as a conservation method, and the genetic monitoring of populations and broodstocks is important to ensure the viability of such programs. The objective of the current unprecedented experiment was to evaluate the genetic diversity of $P$. mesopotamicus wild populations (WPs) and broodstocks (BSs) using microsatellites markers for supplying the restocking programs in the Tietê and Grande rivers. Six microsatellite loci were amplified using the DNA obtained from the caudal fin of 279 adult fish. The observed intrapopulation genetic variability was high with mean heterozygosity ranging from 0.203 to 0.833 . The number of alleles per locus ranged from three (loci Pme28 and Pme32) to thirteen (loci Pme4, Pme5 and Pme14), and there were allele differences between WPsxWPs and WPsxBSs. This differentiation was confirmed by the dendrogram analysis that showed three specific clusters. Four alleles were shared in the WPs2012xBSs. Positive FIS values indicated the presence of endogamy in seven out of ten samples obtained from the WPs. The AMOVA analysis and FST values indicated moderate and high genetic differences in WPsxWPs and high genetic differences in WPsxBSs. The genetic distance and genetic identity values and number of migrants confirmed these results. Adequate intrapopulation genetic variability, similarity between BSsxBSs, and genetic differences between WPs2011xWPs2012 and WPsxBSs were observed. In the wild, individuals from the restocking program were partially observed.

Key words: Genetic conservation, genetic differentiation, microsatellites, Piaractus mesopotamicus, population studies
\end{abstract}

1 Profs. Drs., Dept ${ }^{\circ}$ de Zootecnia, Programa de Pós-Graduação em Zootecnia, Universidade Estadual de Maringá, UEM, Maringá, PR, Brasil.E-mail: rpribeiro@uem.br; lafilho@uem.br; lvargas@uem.br

2 Prof. Dr., Dept ${ }^{\mathrm{O}}$ de Zootecnia, Programa de Pós-Graduação em Ciência Animal, Universidade Estadual de Londrina, UEL, Londrina, PR, Brasil. E-mail: nmlopera@uel.br

3 Gerente de Meio Ambiente, Hidrelétrica AES Tietê-Promissão, Promissão, SP, Brasil. E-mail: silvio.santos@aes.com

${ }^{4}$ Pesquisadora, Universidade Federal dos Vales de Jequitinhonha e Mucuri, UFVJM, Diamantina, MG, Brasil. E-mail: rodrigpilar@ gmail.com

$5 \operatorname{Prof}^{\mathrm{a}} \mathrm{Dr}^{\mathrm{a}}$, Dept ${ }^{0}$ de Zootecnia, Universidade do Oeste do Paraná, UNIOESTE, Marechal Candido Rondon, PR, Brasil. E-mail: she uem@hotmail.com

${ }_{6}^{6}$ Pós-Doutoranda, Programa de Pós-Graduação em Ciência de Alimentos, UEM, Maringá, PR, Brasil. E-mail: elenicesreis@ yahoo.com.br

Discente, Programa de Pós-Graduação em Zootecnia, UEM, Maringá, PR, Brasil. E-mail: pedrocastro.zoo@hotmail.com

${ }^{8}$ Pós-Doutoranda, Dept ${ }^{\circ}$ de Zootecnia, UEL, Londrina, PR, Brasil. E-mail: angelapovedaparra@hotmail.com

* Author for correspondence 


\section{Resumo}

Piaractus mesopotamicus é um peixe tropical que nos últimos anos tem apresentado uma diminuição no número de populações naturais. Programas de repovoamento vêm sendo utilizados como método de conservação, entretanto, o monitoramento genético das populações e dos estoques de reprodutores é importante para conferir a viabilidade desse tipo de programas. O objetivo do presente estudo foi avaliar de forma inédita a diversidade genética de populações selvagens (WPs) e estoques de reprodutores (BSs) de P. mesopotamicus utilizados em programas de repovoamento dos rios Tietê e Grande, através de marcadores microssatélite. Seis loci microssatélite foram amplificados usando DNA extraído de nadadeira caudal de 279 indivíduos adultos. Foi observada alta variabilidade genética intrapopulacional, com medias de heterozigosidade observada entre 0.203 e 0.833 . O número de alelos por locus foi de três (locus Pme28 e Pme32) a 13 (locus Pme4, Pme5 e Pme14) e houve diferenciação de alelos entre WPsxWPs e WPsxBSs. Essa diferenciação foi confirmada pela análise do dendrograma que mostrou a formação de três agrupamentos específicos. Observaram-se quatro alelos compartilhados entre WPs2012xBSs. Valores positivos de $F_{\text {IS }}$ mostraram a presença de endogamia em sete das 10 coletas realizadas nas WPs. A análise de AMOVA e do $F_{\mathrm{ST}}$ indicou moderada e muito alta diferenciação genética entre WPsxWPs e diferenciação genética muito alta em WPsxBSs. Esses resultados foram confirmados pelos valores de distância e identidade genética e pelo número de migrantes. Os resultados demonstraram uma adequada variabilidade genética intra-populacional, similaridade entre BSsxBSs e diferenciação genética entre WPs2011xWPs2012 e WPsxBSs. Observou-se parcialmente a presença de indivíduos oriundos do programa de repovoamento no ambiente natural.

Palavras-chave: Conservação genética, diferenciação genética, estudos populacionais, microssatélites, Piaractus mesopotamicus

\section{Introduction}

Water pollution, deforestation, habitat destruction, overfishing, the introduction of exotic species, and river damming have increased the threats to the wild populations (WPs) of freshwater fish in several rivers in Brazilian basins (BUCKUP et al., 2007; AGOSTINHO et al., 2008). Hydroelectric power plants use river dams to favor local and regional energetic requirements, but they have irreversibly modified the hydrological course of the rivers both biologically and ecologically (AGOSTINHO et al., 2008).

The Tietê and Grande rivers are emphasized as hydric resources in São Paulo State (Brazil). Fiftysix species (from seven orders, 16 families and 40 genera) were observed in the source streams of the Tietê River, but there was a decline in these WPs over the last decade. In the source streams of the Tietê River, Marceniuk et al. (2011) observed ten species at risk for extinction, e.g., the pacu, Piaractus mesopotamicus (Characidae, Serrasalminae Holmberg, 1887). The pacu is currently observed in several hydrographic basins in Brazil and
South America and contributes economically to commercial fishing and fish farming (GARCEZ et al., 2011).

One current activity to increase the wild stock of $P$. mesopotamicus is to develop restocking programs. Although these programs have been performed over several decades, studies of genetic and environmental efficiencies are necessary (AGOSTINHO et al., 2005; POVH et al., 2010). However, many programs have been unsuccessful because of the inappropriate management of broodstocks (BSs) (BORREL et al., 2007; LOPERABARRERO, 2009) and the non-monitoring of WPs. Thus, the genetic evaluation of BSs to participate in restocking programs for WPs must continuously occur (WARD, 2006).

Only a few studies regarding variability and genetic structure using microsatellites markers have been performed in $P$. mesopotamicus WPs and BSs (CALCAGNOTTO; DESALLE, 2009; LOPERA-BARRERO et al., 2010a; POVH et al., 2010, 2011). The microsatellite marker is the most used technique to achieve this purpose and has 
been useful for addressing questions relative to the population diversity and genetic structure of various fish species (NOLAN; POWELL, 2009; AUNG et al., 2010; HULAK et al., 2010; HORNE et al., 2013; MERANER et al., 2013). The objective of the current, unprecedented study was to evaluate the genetic diversity of $P$. mesopotamicus WPs and BSs using microsatellites markers for restocking programs in the Tietê and Grande rivers (Brazil).

\section{Materials and Methods}

Samples of $P$. mesopotamicus caudal fins were collected from an identical area during January 2011 and 2012 from four WPs in the reservoirs of the Água Vermelha - Grande River (AGV1 and
AGV2), Nova Avanhandava - Tietê River (NAV1 and NAV2), Ibitinga - Tietê River (IBI1 and IBI2), and Barra Bonita - Tietê River (BAB1 and BAB2) Hydroelectric Power Plants (HPP). Samples from the WPs Promissão - Tietê River (PRO1) and Bariri - Tietê River (BAR2) were collected in 2011 and 2012, respectively. However, samples were also collected (2012) from four broodstocks (BSs) raised in the Promissão HPP, where one broodstock was formed by juveniles (BSA, BSB, BSC and BSJ) that have been used in restocking programs (Figure 1 and Table 1). These broodstocks were the result of previous samples collected in the Parana River over 15 years when new individuals were introduced from fish collected in the Tietê and Grande rivers in São Paulo State, Brazil.

Figure 1. A geographic map of the sampling locations: 1. Hydroelectric power plant (HPP) Água Vermelha - Grande River (AGV); 2. HPP Nova Avanhandava - Tietê River (NAV); 3. HPP Ibitinga - Tietê River (IBI); 4. HPP Promissão - Tietê River (PRO); 5. HPP Barra Bonita - Tietê River (BAB); 6. HPP Bariri - Tietê River (BAR); 7. Broodstock A (BSA); 8. Broodstock B (BSB); 9. Broodstock C (BSC); and 10. Juvenile Broodstock (BSJ).

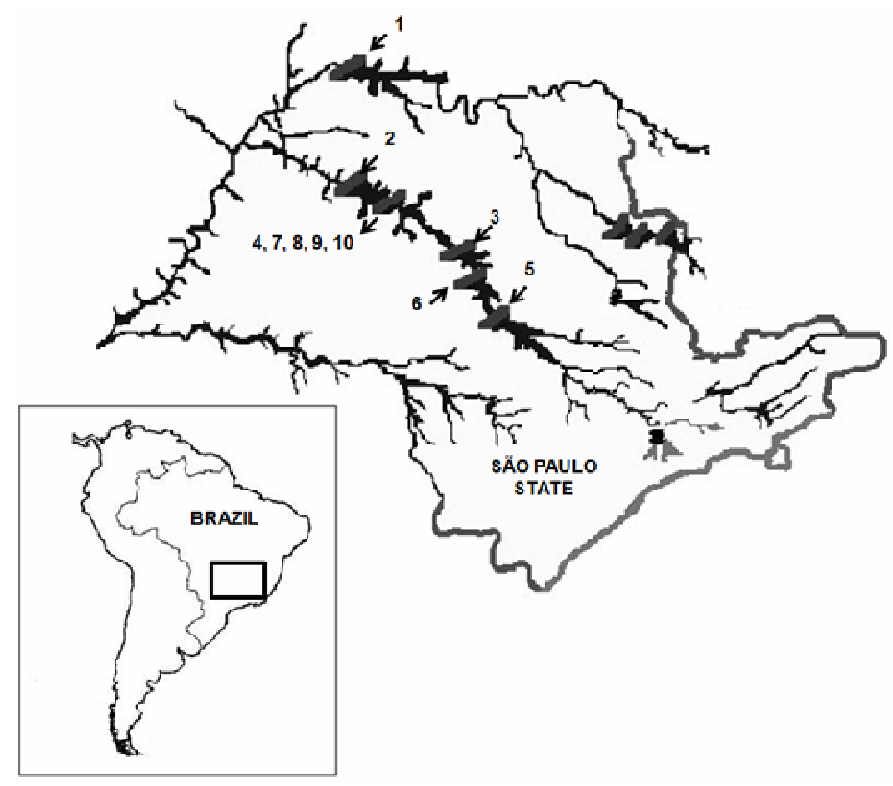

The DNA extraction followed the protocol with $\mathrm{NaCl}$ as reported by Lopera-Barrero et al. (2008). These DNA were quantified using a spectrophotometer with an absorbance of $260 \mathrm{~nm}$. The samples were diluted to $10 \mathrm{ng} \mu \mathrm{L}^{-1}$. The quality of the DNA was assessed by electrophoresis in agarose gel at $1 \%$ using a TBE $1 \mathrm{X}$ buffer $\left(500 \mathrm{mM} \mathrm{L}^{-1}\right.$ Tris$\mathrm{HC1}, 60 \mathrm{mM} \mathrm{L}^{-1}$ boric acid and $83 \mathrm{mM} \mathrm{L}^{-1}$ EDTA) for one hour at $70 \mathrm{~V}$. The gel was observed under UV radiation after exposure to ethidium bromide $\left(0.5 \mathrm{mg} \mathrm{mL}^{-1}\right)$ for one hour. The images were then photographed using the transilluminator program. 
Table 1. Characteristics of the Piaractus mesopotamicus populations.

\begin{tabular}{|c|c|c|c|c|c|}
\hline Populations & Codes & $\begin{array}{l}\text { Sampling } \\
\text { size }\end{array}$ & $\begin{array}{c}\text { Operating } \\
\text { year }\end{array}$ & Latitude & Longitude \\
\hline UHE Água Vermelha 2011 & AGV1 & 04 & 1978 & $19^{\circ} 52^{\prime} 04$ "S & $50^{\circ} 20^{\prime} 43^{\prime \prime} \mathrm{W}$ \\
\hline UHE Água Vermelha 2012 & AGV2 & 26 & 1978 & $19^{\circ} 52^{\prime} 04^{\prime \prime} \mathrm{S}$ & $50^{\circ} 20^{\prime} 43^{\prime \prime} \mathrm{W}$ \\
\hline UHE Nova Avanhandava 2011 & NAV1 & 10 & 1982 & $21^{\circ} 07^{\prime} 05^{\prime \prime} \mathrm{S}$ & $50^{\circ} 12^{\prime} 02^{\prime \prime} \mathrm{W}$ \\
\hline UHE Nova Avanhandava 2012 & NAV2 & 11 & 1982 & $21^{\circ} 07^{\prime} 05^{\prime \prime} \mathrm{S}$ & $50^{\circ} 12^{\prime} 02^{\prime \prime} \mathrm{W}$ \\
\hline UHE Ibitinga 2011 & IBI1 & 03 & 1969 & $21^{\circ} 45^{\prime} 33^{\prime \prime} \mathrm{S}$ & $48^{\circ} 59^{\prime} 26^{\prime \prime} \mathrm{W}$ \\
\hline UHE Ibitinga 2012 & IBI2 & 21 & 1969 & $21^{\circ} 45^{\prime} 33^{\prime \prime} \mathrm{S}$ & $48^{\circ} 59^{\prime} 26^{\prime \prime} \mathrm{W}$ \\
\hline UHE Promissão 2011 & PRO1 & 30 & 1975 & $21^{\circ} 17^{\prime} 52^{\prime \prime} \mathrm{S}$ & $49^{\circ} 47^{\prime} 20^{\prime \prime} \mathrm{W}$ \\
\hline UHE Barra Bonita 2011 & BAB1 & 13 & 1963 & $22^{\circ} 31^{\prime} 10^{\prime \prime} \mathrm{S}$ & $48^{\circ} 32^{\prime} 00^{\prime \prime} \mathrm{W}$ \\
\hline UHE Barra Bonita 2012 & BAB2 & 16 & 1963 & $22^{\circ} 31^{\prime} 10^{\prime \prime} \mathrm{S}$ & $48^{\circ} 32^{\prime} 00^{\prime \prime} \mathrm{W}$ \\
\hline UHE Bariri 2012 & BAR2 & 26 & 1965 & $22^{\circ} 09^{\prime} 11^{\prime \prime} \mathrm{S}$ & $48^{\circ} 45^{\prime} 08^{\prime \prime} \mathrm{W}$ \\
\hline Broodstock A & BSA & 30 & 1997 & $21^{\circ} 17^{\prime} 52^{\prime \prime} \mathrm{S}$ & $49^{\circ} 47^{\prime} 20^{\prime \prime} \mathrm{W}$ \\
\hline Broodstock B & BSB & 30 & 1997 & $21^{\circ} 17^{\prime} 52^{\prime \prime} \mathrm{S}$ & $49^{\circ} 47^{\prime} 20^{\prime \prime} \mathrm{W}$ \\
\hline Broodstock C & $\mathrm{BSC}$ & 29 & 1997 & $21^{\circ} 17^{\prime} 52^{\prime \prime} \mathrm{S}$ & $49^{\circ} 47^{\prime} 20^{\prime \prime} \mathrm{W}$ \\
\hline Juvenile Broodstock & BSJ & 30 & 1997 & $21^{\circ} 17^{\prime} 52^{\prime \prime} \mathrm{S}$ & $49^{\circ} 47^{\prime} 20^{\prime \prime} \mathrm{W}$ \\
\hline
\end{tabular}

The DNA was amplified to a final volume of $20 \mu \mathrm{L}$ using $1 \mathrm{X}$ of Tris-KCl buffer, $2.0 \mathrm{mM} \mathrm{L}^{-1}$ of $\mathrm{MgCl}_{2}, 0.8 \mu \mathrm{M} \mathrm{L}^{-1}$ of each primer (Forward and Reverse), $0.4 \mathrm{mM} \mathrm{L}^{-1}$ of each dNTP, $1 \mathrm{U}$ of Platinum Taq DNA Polymerase and $20 \mathrm{ng}$ of DNA. The DNA was initially denaturized at $94{ }^{\circ} \mathrm{C}$ for $4 \mathrm{~min}$ followed by denaturation for 30 cycles at $94{ }^{\circ} \mathrm{C}$ for $30 \mathrm{~s}$, annealing for $30 \mathrm{~s}$ with a different temperature for each primer (Table 2), extension at $72{ }^{\circ} \mathrm{C}$ for 1 min, and the final extension at $72{ }^{\circ} \mathrm{C}$ for $10 \mathrm{~min}$. Six loci described by Calcagnotto et al. (2001) were amplified (Table 2).

The amplified samples were submitted to electrophoresis in $10 \%$ polyacrylamide gel (29:1 of acrylamide:bisacrylamide) denaturized with $6 \mathrm{M}$ $\mathrm{L}^{-1}$ of urea, and placed in TBE $1 \mathrm{X}$ buffer $(90 \mathrm{mM}$ of Tris-Borate and $2 \mathrm{mM}$ of EDTA) at $320 \mathrm{~V}$ and $250 \mathrm{~mA}$ for seven hours. The microsatellite alleles were visualized using silver nitrate following the method modified by Bassam et al. (1991). The gel was washed in fixing solution with $10 \%$ ethanol and $0.5 \%$ acetic acid for $20 \mathrm{~min}$; thereafter, the gel was stained ( $6 \mathrm{mM}$ of silver nitrate) for $10 \mathrm{~min}$, visualized $(0.75 \mathrm{M}$ of $\mathrm{NaOH}$ and $0.20 \%$ of phormol $-40 \%$ ) and photographed with a digital camera.

The allele size was calculated using a DNA ladder (Invitrogen) of 10, 50 and $100 \mathrm{bp}$. The type and size of the alleles, obtained from microsatellite loci, in the $P$. mesopotamicus populations (80 $270 \mathrm{bp}$ ) were organized into data matrices using computer software to estimate several parameters of intra- and interpopulation genetic diversity.

Table 2. Characteristics of the six microsatellite loci used in the current study.

\begin{tabular}{|c|c|c|c|c|}
\hline Locus & Repeat motifs & Primer sequence $5^{\prime}-3{ }^{\prime}$ & $\begin{array}{c}\text { Annealing } \\
\text { temperature }\left({ }^{\circ} \mathrm{C}\right)\end{array}$ & GenBank \\
\hline Pme2 & $(\mathrm{GT}) 18$ & $\begin{array}{l}\text { F: TGGGTGCACAGCACAGTAAC } \\
\text { R: TTTGCATTTCTGGTGCAAAG }\end{array}$ & 60 & AF362445 \\
\hline Pme4 & $(\mathrm{GT}) 14$ & $\begin{array}{l}\text { F: CATGCTGCTGCAGATTAGAC } \\
\text { R: CGCTTGCAATTTAACGCAGT }\end{array}$ & 60 & AF362446 \\
\hline
\end{tabular}


continuation

\begin{tabular}{cclcc} 
Pme5 & $\begin{array}{c}(\mathrm{GA}) 10 \\
\text { gggagctggta } \\
(\mathrm{GT}) 10 \mathrm{C}(\mathrm{GT}) 12\end{array}$ & $\begin{array}{l}\text { F: CAGAGCATCTGGAGGGACAT } \\
\text { R: TCTGAGACACTGATATCTAAACACACA }\end{array}$ & 60 & AF362447 \\
Pme14 & $(\mathrm{CTG}) 7$ & F: ACCGTTATGCCCTACCCTTC & & \\
& R: GCGTTCTAGACAGAACTCATGG & 62 & AF362448 \\
Pme28 & $($ GT $) 15$ & $\begin{array}{l}\text { F: CCCAGAAGAGTGGAAGCTGT } \\
\text { P: TGGTGGGAATTGACAAGAAA }\end{array}$ & 60 & AF362451 \\
& & F: GCGAGAAATCTGCCTGTGAC & & \\
& $(\mathrm{CTG}) 7$ & 66 & AF362452 \\
\hline
\end{tabular}

The number of alleles, the observed (Ho) and expected (He) heterozygosities, Hardy-Weinberg equilibrium test (HWE), migratory number (Nm) and fixation index (FIS) of Wright (1978) were calculated for every locus using the GENEPOP 4.0.6 software (ROUSSET, 2008). In the HWE test, the deficiency or excess of heterozygotes per loci was based on Fisher's Exact Test calculated using a Markov chain (Markov chain length: 100,000; dememorizations: 10,000). The allelic frequency, distance (GD) and genetic identity (GI) were calculated using PopGene 1.31 software (YEH et al., 1999). The allelic richness (AR) was calculated using FSTAT 2.9.3.2 software (GOUDET, 2002). The presence of null alleles was verified using MicroChecker 2.2.3 software (VAN OOSTERHOUT et al., 2004). The values of genetic differentiation (FST) (WEIR; COCKERHAM, 1984), the linkage disequilibrium and analysis of molecular varianceAMOVA were estimated using Arlequin 3.1 software (EXCOFFIER et al., 2005). In these final analyses, the populations were discriminated by all allowed combinations (91). For the discriminatory method of the FST values, we followed Wright (1978), in which the values from 0.00 to $0.05,0.051$ to $0.15,0.151$ to 0.25 and $>0.25$ indicated small, moderate, high and higher genetic differentiation, respectively. An unweighted pair-group mean analysis (UPGMA) tree was constructed based on Nei's genetic distance (NEI, 1978) of pairwise locations using MEGA 5.0 software (TAMURA et al., 2011). The reduction in the effective population size was calculated by Bottleneck 1.2.02 software (CORNUET; LUIKART, 1996) using the I.A.M. (model of infinity alleles) mutation model and Wilcoxon sign-rank test. The P-values were adjusted following Bonferroni's sequential corrections for multiple simultaneous statistical tests (RICE, 1989).

\section{Results}

A total of 50 alleles were detected from 279 individuals in 10 WPs and four BSs evaluated by six loci. These loci were polymorphic, and the amplified microsatellite alleles were consistent and reproducible with sizes ranging from 80 (Pme5) to 270 bp (Pme4). The Pme4, Pme5 and Pme14 loci had many alleles (13 alleles) followed by Pme2 (5 alleles), Pme28 and Pme32 (3 alleles) (Table 3). The average number of alleles in every locus and population ranged from 2.25 (IBI1) to 4.50 (AGV2 and BSB).

The 2011 and 2012 WPs and WPsxBSs were characterized by one different allele amplification. Compatible alleles were not observed in these WPs. In these WPs, the Pme2 locus was not amplified, and the Pme28 (2011) and Pme32 (2012) loci were observed in every sampling. However, there was exclusive amplification of the Pme2 locus in the BSs and no amplification of the Pme28 or Pme 32 loci. Only four alleles were compatible with the WPs in 2012 (Pme4: 95 and 100 bp; Pme14: 95 and 105 bp) (Table 3 ).

Alleles with low frequencies (lower than 0.1) were observed in eight out of ten WPs with many located in AGV2 (nine alleles), PRO1, IBI2 and BAB2 (three alleles). The lowest allelic frequency 
(0.019) was observed in the Pme14 locus (95 bp) from AGV2 and the highest (1.000) from AGV1 (Pme14, 230 bp). All BSs had low frequency alleles, particularly BSJ (eight alleles) and BSC (six alleles). The lowest frequency (0.017) was observed in the Pme14 (110 bp), Pme14 (110 bp) and Pme2 (115 bp) loci from BSA, BSC and BSC, respectively. The highest frequency (0.780) was observed in the Pme14 locus (100 bp) (Table 3). Null alleles were observed in BAB1, AGV2, NAV2, IBI2, BAR2 and $\mathrm{BAB} 2$, but there was no linkage disequilibrium.

Differences $(\mathrm{P}<0.01)$ in the Ho and $\mathrm{He}$ from all the WPs and BSs were observed for all loci. These data were characterized by Hardy-Weinberg disequilibrium. The average Ho in every locus ranged from 0.000 (Pme4: BAB2; Pme14: NAV2) to 0.967 (Pme2: BSB). In the Pme4 (IBI1), Pme5 (AGV1), Pme14 (AGV1) and Pme28 (IBI1) loci, there was $100 \%$ heterozygosity. Based on studies of WPs of Piaractus (CALCAGNOTTO; DESALLE, 2009; LOPERA-BARRERO et al., 2010a; POVH et al., 2011) the average Ho was high (>45\%) from AGV1, NAV1, IBI1, PRO1, BAB1 and in the $\mathrm{BSs}$, which indicated high intrapopulation genetic variability. AGV2, NAV2, IBI2, BAR2 and BAB2 had heterozygosities ranging from 0.203 to 0.394 . These results in conjunction with the low frequency alleles indicated that the genetic variability was lower in these populations. The AR was different among the groups $(\mathrm{P}<0.05)$, but in 2012, it was lower in the WPs after the Bonferroni correction (Table 4).

Negative mean values of the coefficient (FIS) from AGV1, NAV1, IBI1, BSA, BSB, BSC and BSJ (from -0.070 to -0.364 ) indicated no endogamy. By contrast, the positive values from PRO1, BAB1, AGV2, NAV2, IBI2, BAR2 and BAB2 (from 0.007 to 0.672 ) indicated the presence of endogamy, and all the cases from these data were characterized by Hardy-Weinberg disequilibrium (Table 4). The results also indicated that the WPs and BSs were experiencing mutation disequilibrium and drift because of a recent bottleneck effect, except in AGV1 (Pme28), AGV2 (Pme4), NAV2 (Pme4 and Pme32) and IBI2 (Pme14).

Based on the AMOVA, the highest genetic variation $(\mathrm{P}<0.05)$ was observed within groups with a general FST value of 0.3403 , which indicated high genetic differences in the WPs in 2011 and 2012 following the Wright classification. The analysis of the FST in terms of the differences for all WPs combinations (45) indicated that the values ranged from 0.008 (NAV1xBAB1) to 0.625 (IBI1xIBI2), which suggested small and high genetic differences, respectively, based on the identical classification. Similarly, the results of $\mathrm{Nm}$ had high and low gene flow among the populations with values from 0.21 (AGV1xIBI1) to 6.97 (PRO1xBAB1) individuals per generation (Table 5).

The GD and GI results indicated genetic differences among the WPs in both years (0.000). In 2011, the values ranged from 0.022 (IBI1xPRO1) to 0.355 (AGV1xBAB1) for $\mathrm{GD}$ and from 0.701 (AGV1xBAB1) to 0.978 (IBI1xPRO1) for GI. In 2012, the GD ranged from 0.145 (NAV2xIBI2) to 0.671 (AGV2xBAB2), and the GI ranged from 0.511 (AGV2xBAB2) to 0.978 (NAV2xIBI2) (Table 5).

In the BSs, the GD (from 0.021 to 0.066 ) and GI (from 0.936 to 0.979 ) results indicated high genetic similarities (Table 5). According to the AMOVA, the largest genetic variation $(\mathrm{P}<0.05)$ was observed within the groups with a general FST value of 0.0287 , which indicated small genetic differences based on the Wright classification. The FST analysis from all six WP combinations indicated that the values ranged from 0.006 (BSAxBSB) to 0.051 (BSCxBSJ), which suggested small genetic differences based on the Wright classification. Similarly, the Nm results indicated high gene flow among the populations with values from 6.35 (BSCxBSJ) to 22.30 (BSAxBSB) individuals per generation (Table 5). 


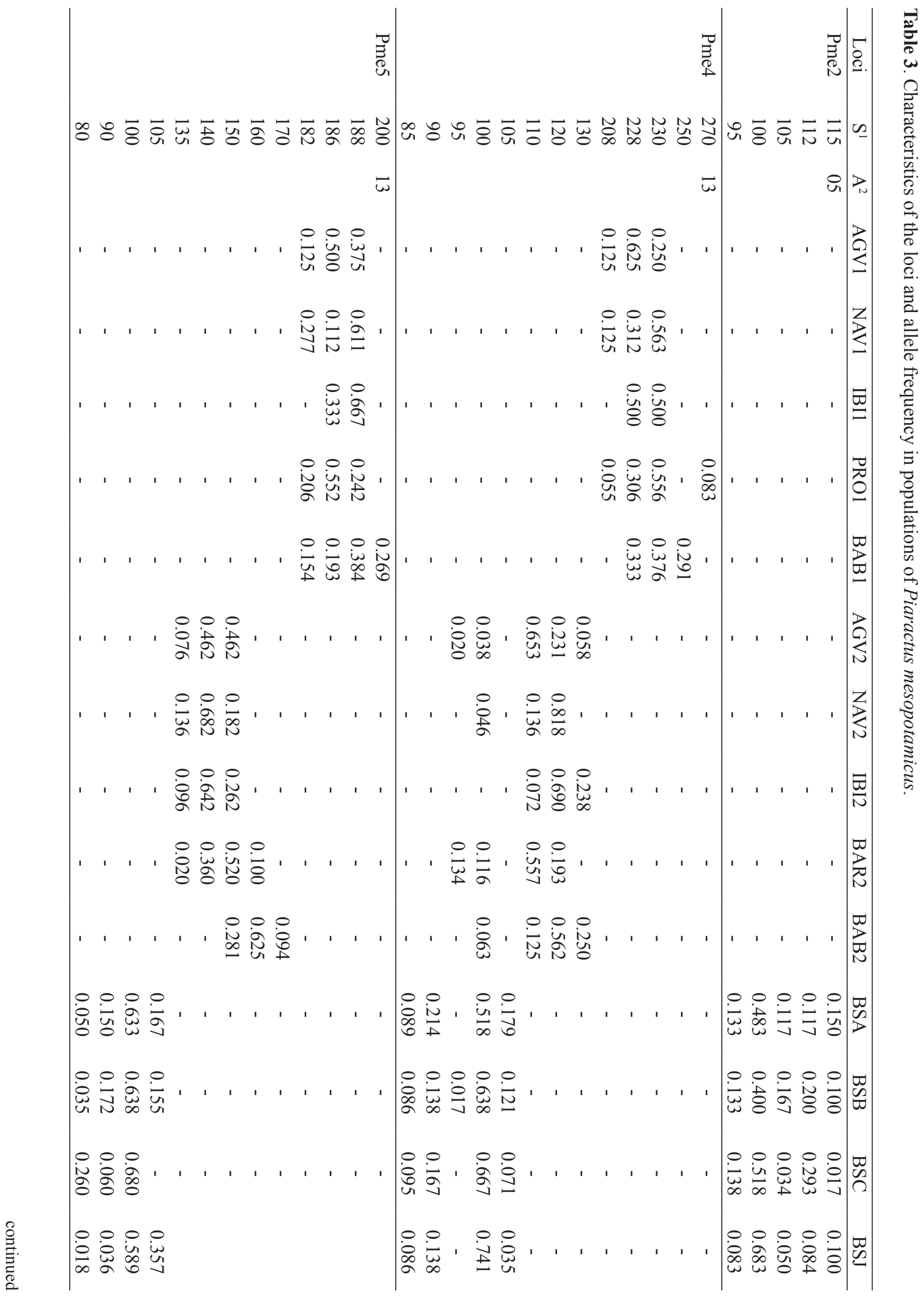




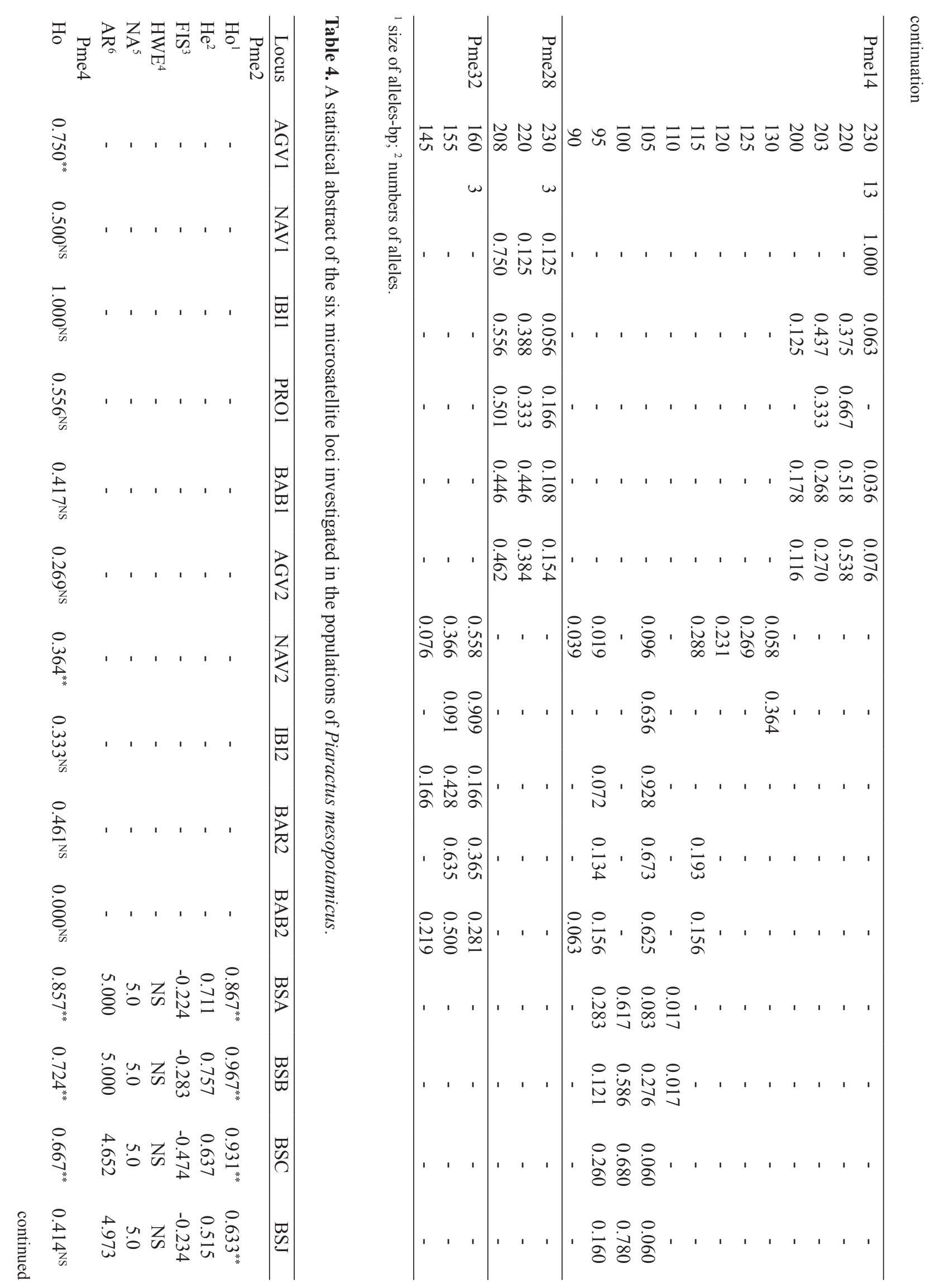




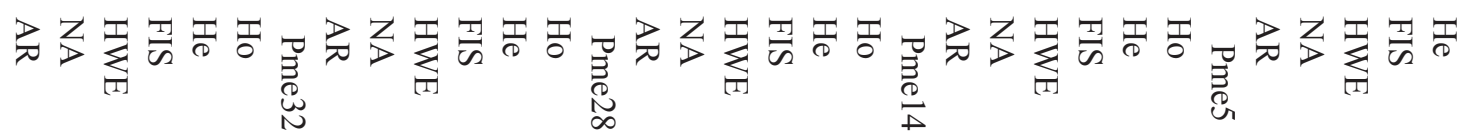

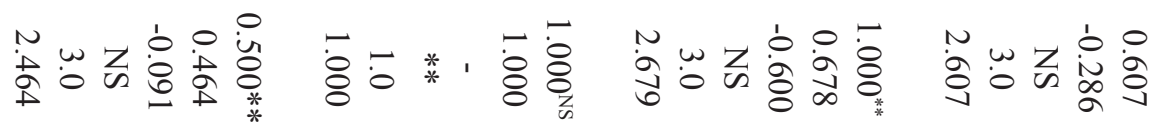

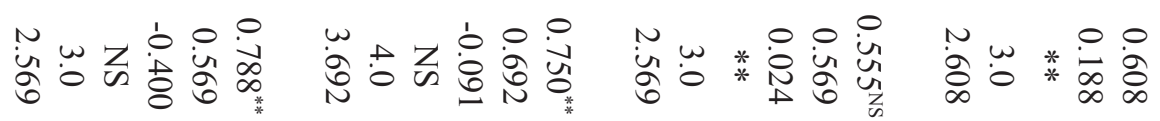

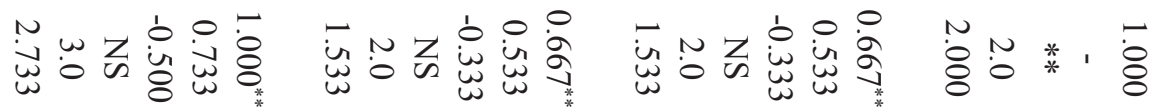

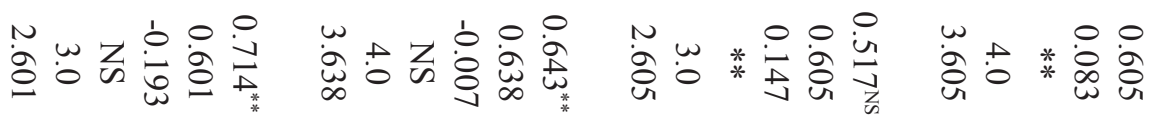

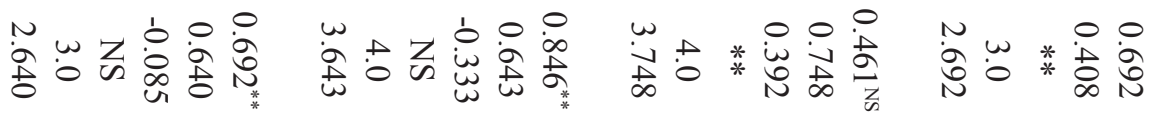

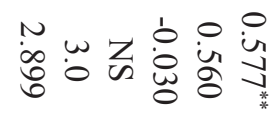

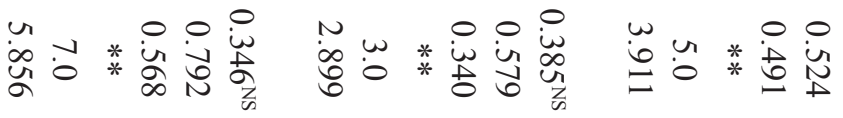

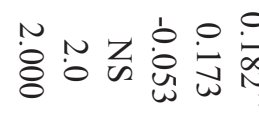

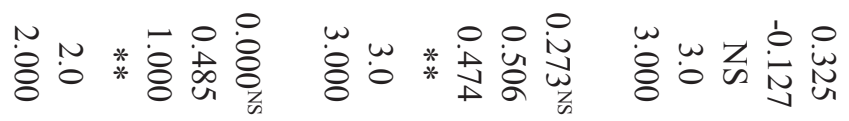

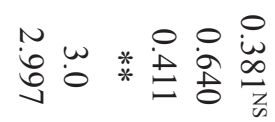

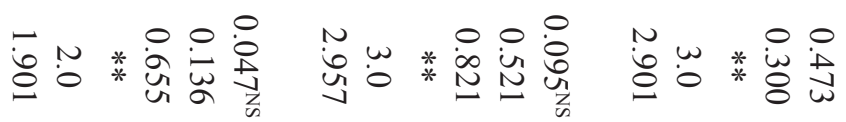

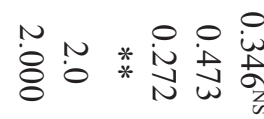

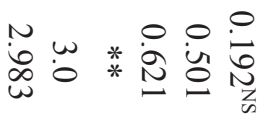

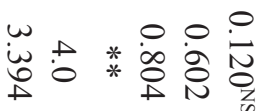

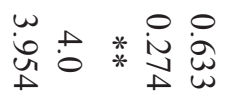

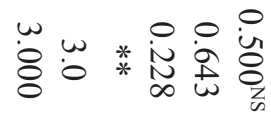

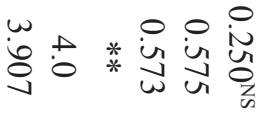

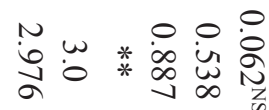
岂: *

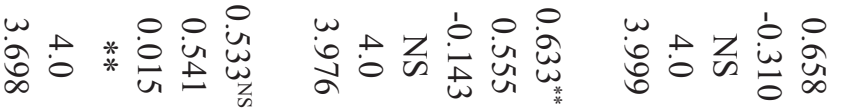

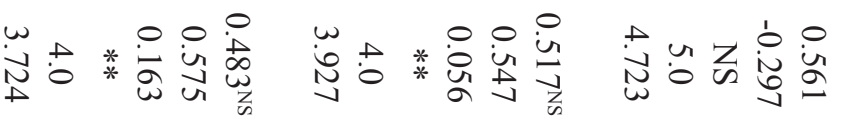

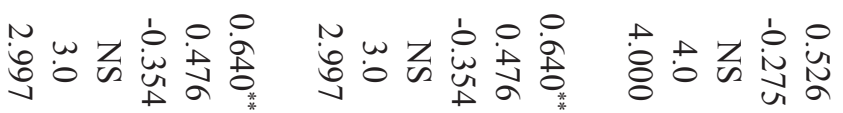

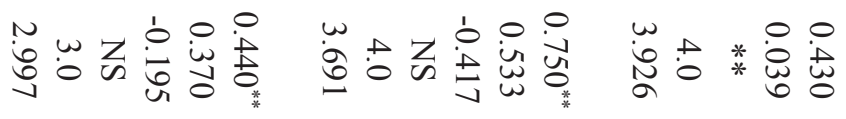




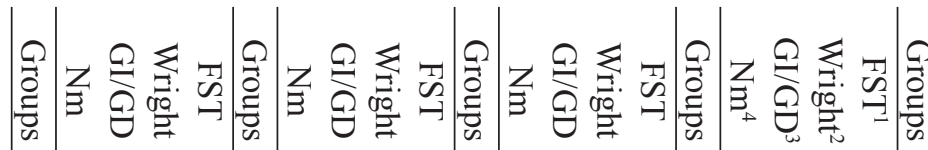

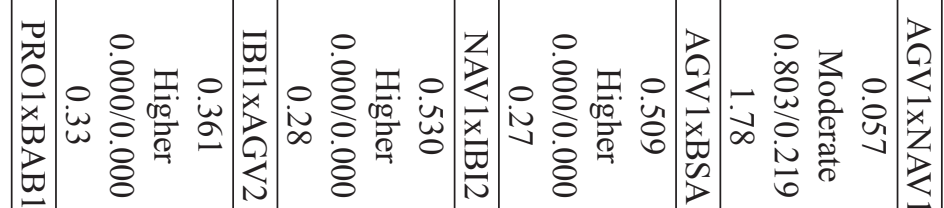

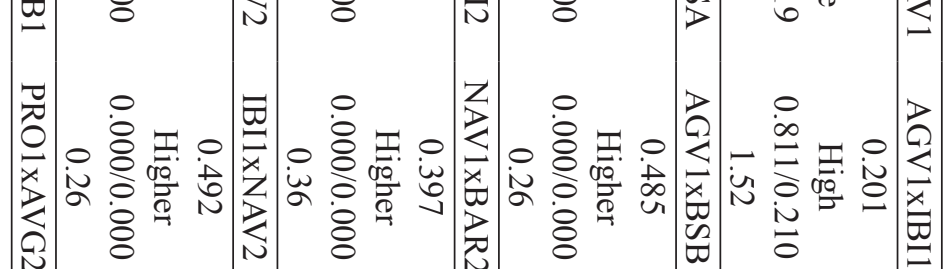

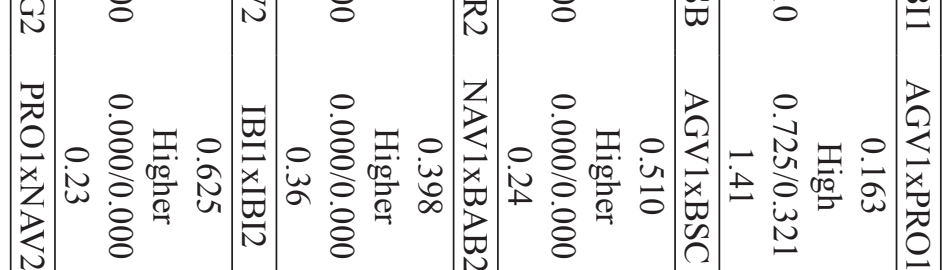

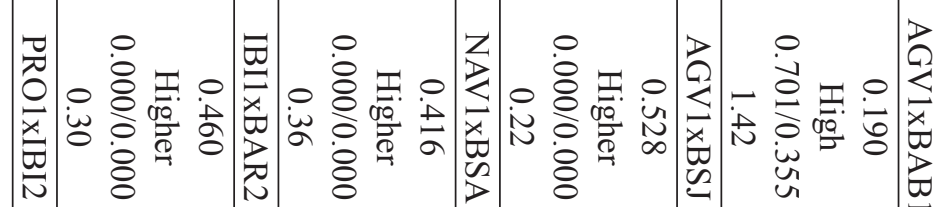

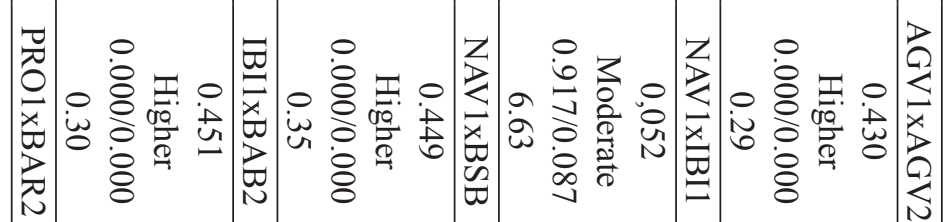

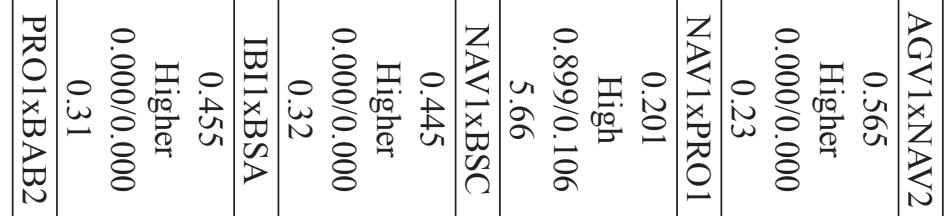

勿

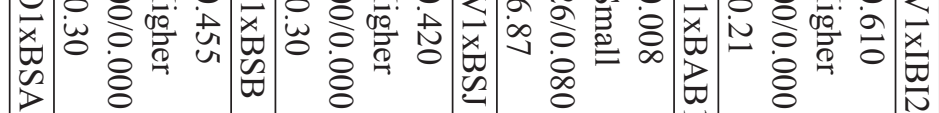

勿

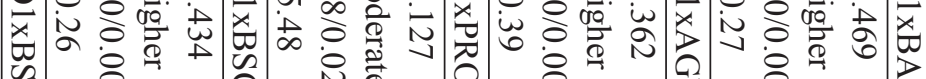

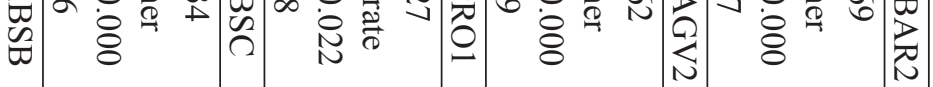

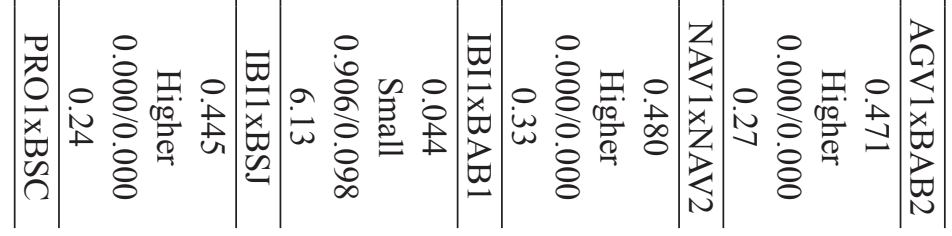

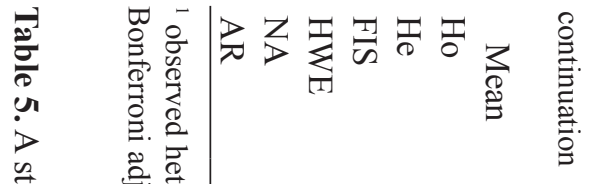

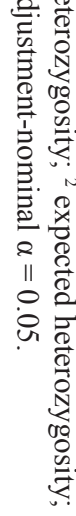

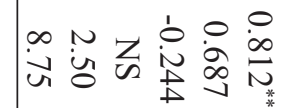

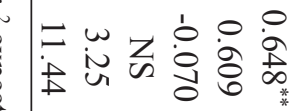

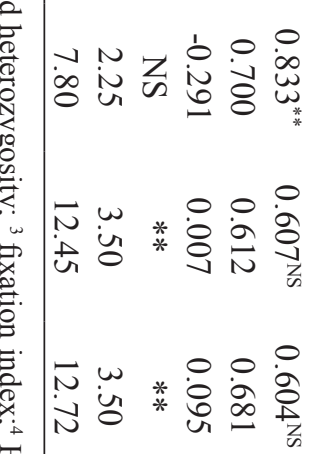

:

.

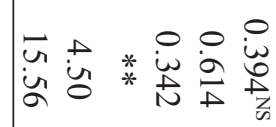

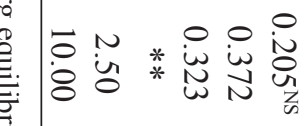

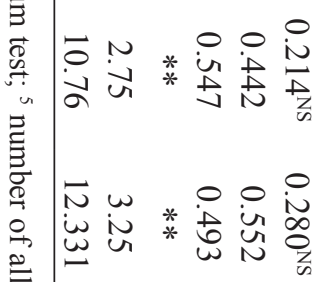

$\stackrel{2}{\frac{\infty}{\infty}}$

(2)

帘

(2)

害 


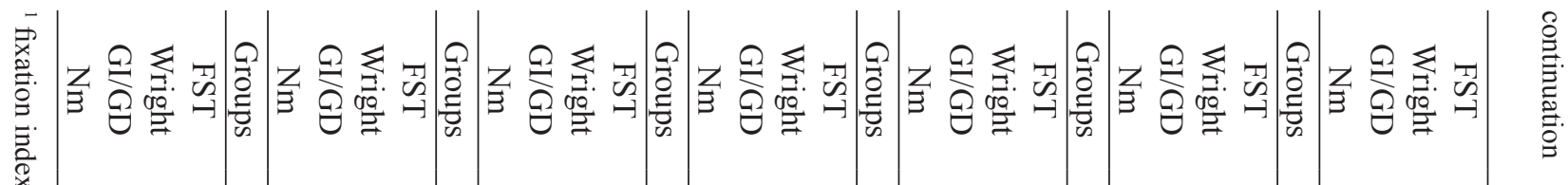

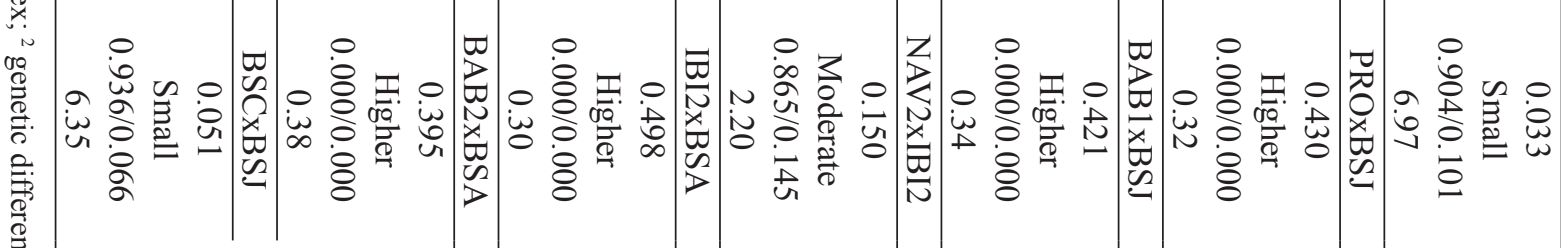

党

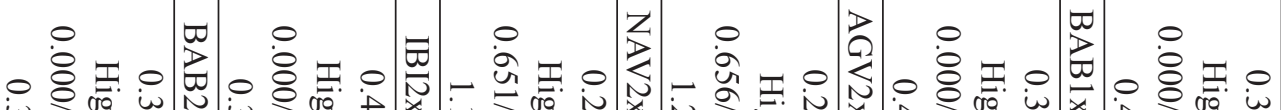

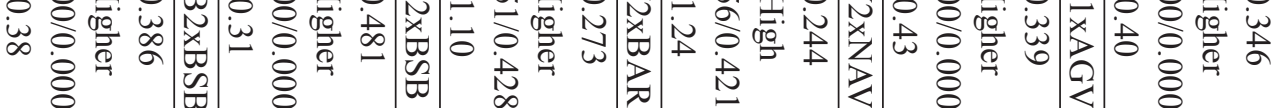

$\sum_{\substack{0.0 \\ \text { wat }}}$

$\stackrel{\overbrace{}}{\stackrel{\overbrace{}}{\sigma}}$

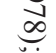

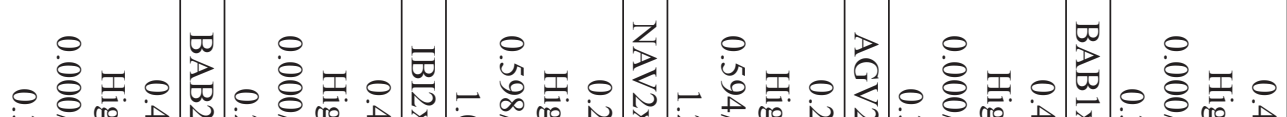

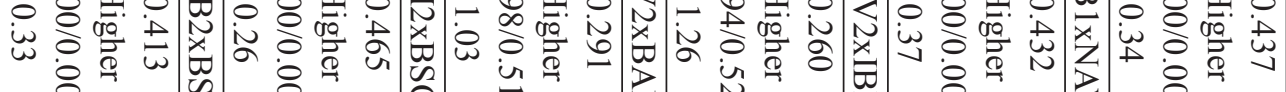

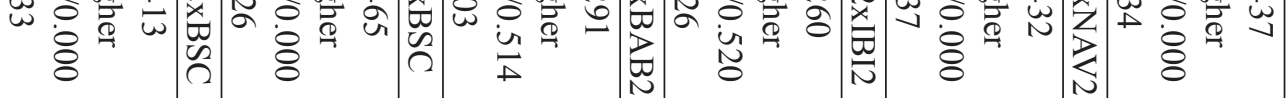

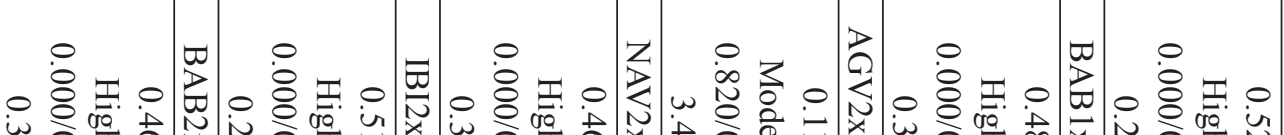

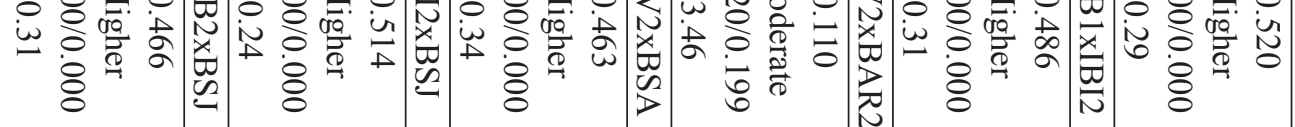

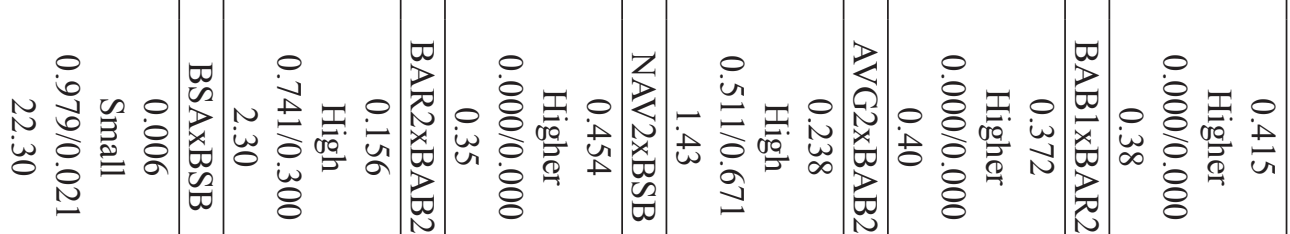

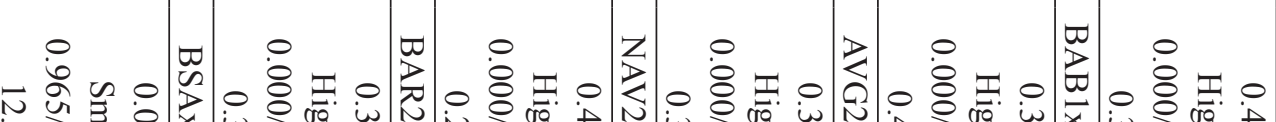

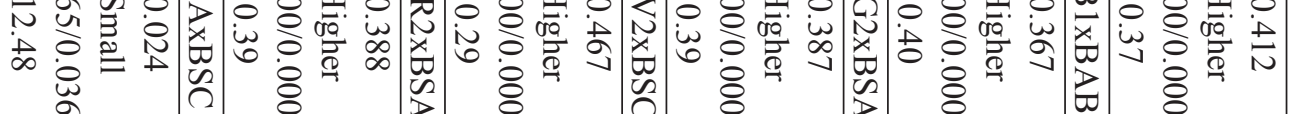

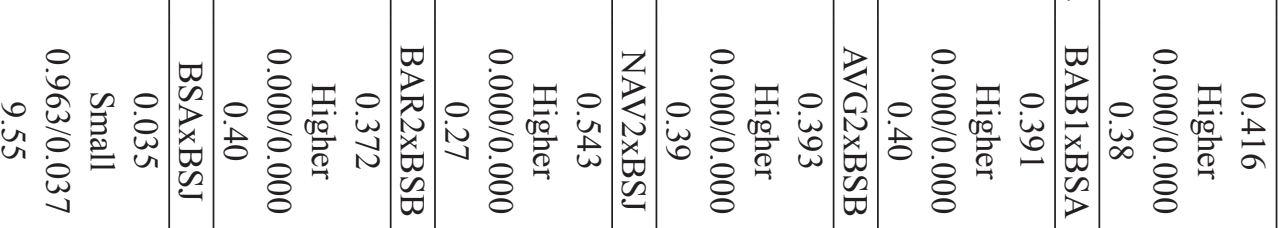

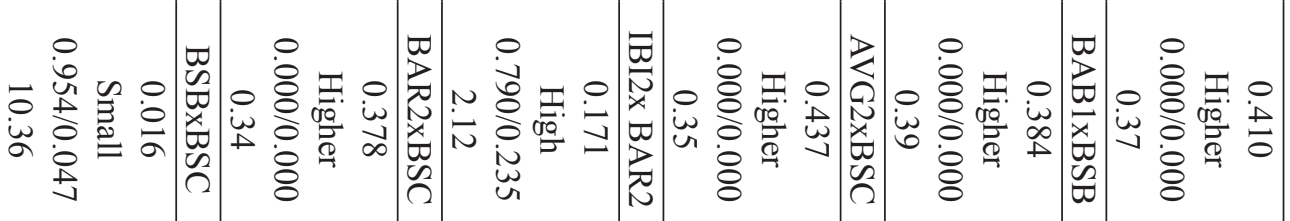

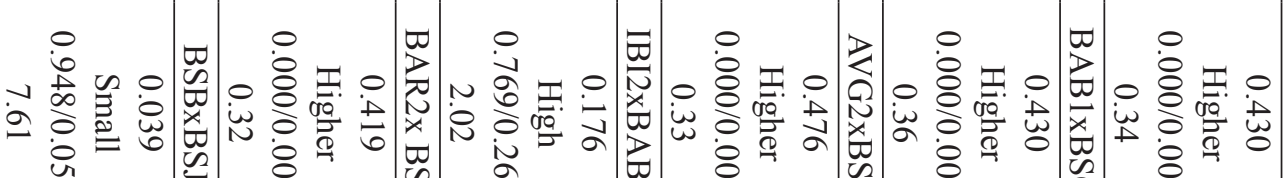

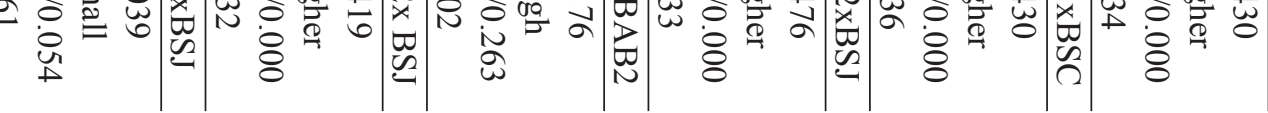


Finally, comparing the WPs (2011 and 2012) and $\mathrm{BSs}$, the GD and GI results indicated high genetic differences, thus corroborating the results from the allelic frequencies. Based on the AMOVA, the largest genetic variation $(\mathrm{P}<0.05)$ was detected in groups with an FST of 0.3746 , which indicated high genetic differences based on the Wright classification. Using all 40 combinations, the FST values ranged from 0.372 (BAR2xBSB) to 0.528
(AGV1xBSJ), which also suggested high genetic differences. Similarly, the Nm results indicated lower gene flow among the populations because the values ranged from 0.22 (AGV1xBSJ) to 0.41 (BAR2xBSB) individuals per generation (Table 5). The UPGMA dendrogram showed two specific groups: one for the WPs and BS sampled in 2011 and the other for the WPs from 2012 (Figure 2).

Figure 2. The unweighted pair-group mean analysis (UPGMA) of the tree from 10 populations of Piaractus mesopotamicus: Hydroelectric power plant (HPP) Água Vermelha - Grande River (AGV); HPP Nova Avanhandava Tietê River (NAV); HPP Ibitinga - Tietê River (IBI); HPP Promissão - Tietê River (PRO); HPP Barra Bonita - Tietê River (BAB); HPP Bariri - Tietê River (BAR); Broodstock A (BSA); Broodstock B (BSB); Broodstock C (BSC); and Juvenile Broodstock (BSJ). Source: Elaboration of the authors.

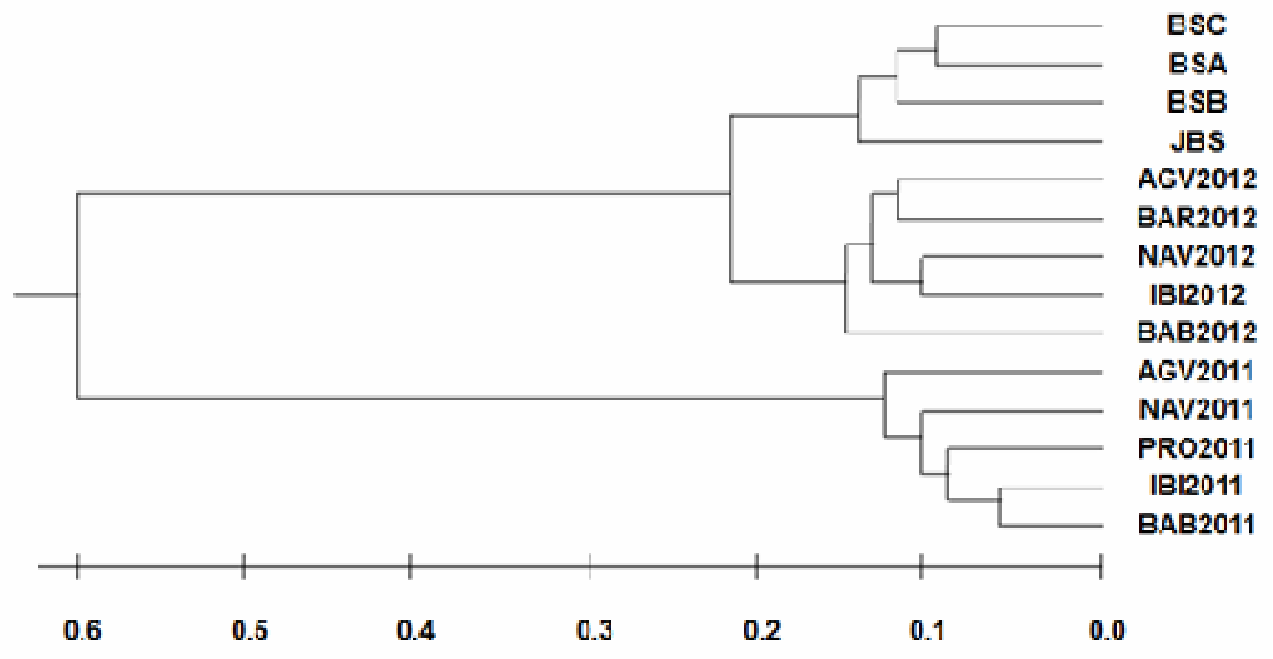

\section{Discussion}

\section{Genetic variability}

The current loci were highly polymorphic and amplified microsatellites alleles with consistency and reproducibility. This high degree of polymorphism indicated that every locus may be used in population studies (FOPP-BAYAT et al., 2010). Fifty alleles distributed in several loci (Pme2: 05 alleles, Pme4: 13 alleles, Pme5: 13 alleles, Pme14: 13 alleles, Pme28: 03 alleles and Pme32: 03 alleles) were detected. In WPs, the number of alleles was higher (Pme4, Pme5, Pme14 and Pme32) and lower (Pme28) than reported by Calcagnotto and DeSalle (2009), and by comparison, was higher (Pme2 and Pme14), similar (Pme32) and lower (Pme28) than stated by LoperaBarrero et al. (2010a). In BSs, the number of alleles was higher (Pme14, Pme28), similar (Pme2, Pme4, Pme32) and lower (Pme5) than reported by Povh et al. (2011). According to $\mathrm{Mu}$ et al. (2011), such differences might be a response to the sampling size in the respective experiments. The geographic location of the different rivers and basins might also have affected such numbers because every population has a pool of alleles specific to regional and local adaptations. 
The presence of exclusive alleles in the WPs sampled in 2011 and 2012 was an indication of different genetic origins. This result could be explained by the migratory performance of $P$. mesopotamicus at the beginning of the reproductive, period that occurs from September to March (RESENDE, 2003). Thus, in the sampling period (January), a large migration of $P$. mesopotamicus might have occurred, and the samples from 2011 and 2012 were most likely obtained from different populations collected in the identical location.

No genetic similarity was observed in the analyses of the alleles between the WPs and BS populations. However, the sharing of four alleles with the WPs from 2012 (Pme4: 95 and 100 bp; Pme14: 95 and 105) suggested the presence in the WPs of fish from the restocking program (BSs). For more than 15 years, the restocking program from the AES Company has released fingerlings (90 days old) into the Tietê and Grande rivers. Genetic monitoring had never been performed to show that released individuals have adapted and gathered into new populations. Thus, only four alleles indicate this important biological and genetic result. Similar results were also reported by Lopera-Barrero et al. (2010a) who observed allele sharing between WPs and BSs of Piaractus mesopotamicus from restocking programs on the Paranapanema River (Brazil).

The Ho from the BSs was high and without deviation in the Hardy-Weinberg equilibrium (HWE), thus indicating high genetic variability. In comparison, a lower heterozygosity in BSJ (Ho $=0.559)$ was observed. The difference $(\mathrm{P}<0.01)$ between $\mathrm{Ho}$ and $\mathrm{He}$ in all WPs was characterized by heterozygote deficiencies in the HWE. This difference (typical in fish populations) might have occurred from population fragmentation, the Wahlund effect (WILSON et al., 2004), endogamy (O'CONNELL; WRIGHT, 1997), or the bottleneck effect (AGOSTINHO et al., 2007). Based on these concepts, the difference in the average Ho in the 2011 and 2012 WPs might have resulted from the
Wahlund effect, thus indicating a population structure in which random mating occurred (WILSON et al., 2004). This effect was corroborated by exclusive alleles for each year and the biological performance of the fish during the "piracema" period.

The results of the average Ho were high for AGV1, NAV1, IBI1, PRO1, BAB1, BSA, $\mathrm{BSB}, \mathrm{BSC}$ and $\mathrm{BSJ}$, which indicated adequate intrapopulation genetic variability and the maintenance of variability despite the deficit of heterozygotes. Calcagnotto and DeSalle (2009) analyzed P. mesopotamicus populations and Carvalho-Costa et al. (2008) analyzed Prochilodus costatus populations and observed high genetic variability in these populations with heterozygosity deficits at some loci.

The lowest values of Ho were observed in AGV2, NAV2, IBI2, BAR2 and BAB2, which indicated low genetic variability in concordance with low frequency alleles. These results could be attributed to a decrease in the number of individuals in the WPs (bottleneck effect), which is likely caused by dam effects, overfishing, environmental modifications, or a combination of these variables. In general, this effect always occurs with homozygote excess (NANAKORN; MOEIKUM, 2009), induces the loss of alleles, increases genetic drift and reduces genetic variability.

Dams and Hydroelectric Power Plants (HPP) do not to allow WPs of migratory fish to pass upstream to reach their reproduction locations (DEHAIS et al., 2010). The study by Makrakis et al. (2007) from 1997 to 2005 in the Paraná River Basin in Brazil, Paraguay and Argentina observed a migratory path for Piaractus mesopotamicus stretching up to $422 \mathrm{~km}(26.4 \mathrm{~km} / \mathrm{day})$. This result shows the biological drive for long migrations, which has been reduced by habitat fragmentation promoted by dams in the current region. This fragmentation and geographic isolation have also affected gene flow and caused the formation of populations with only a few individuals; consequently, erosion and losses 
in genetic variability are worsened by isolated generations (FALCONER, 1989; RIBOLLI et al., 2012). Overfishing may be another factor that reduces the number of individuals, thus promoting a genetic bottleneck that reduces genetic variability. Finally, the hydric sources in this study (the Tietê and Grande Rivers) have undergone several environmental changes because of pollution, alluvial sedimentation, deforestation, destruction of the riverbank habitat and the introduction of exotic species, which have modified the river biology and aquatic communities because of parallel effects on food availability. All of these factors can cause fish mortality that reduces the effective population size and consequently decreases genetic variability.

Allelic richness (AR), which represents the number of alleles segregated in the population (CABALLERO et al., 2010), was lower in the BSs than in WPs. This result, also confirmed by the average Ho, showed the historical fluctuation in BSs population size (foundation effect), which was expected because the conjunction of BSs genes compared to WPs is typically characterized by lower genetic variability (FOPP-BAYAT, 2010). However, the genetic variability of BSs remained high, which indicated good reproductive management.

The average FIS value indicated no endogamy in AGV1, NAV1, IBI1, BSA, BSB, BSC and BSJ. In the $\mathrm{BSs}$, this result confirmed the foundation effect as the main cause of lower allelic richness. Endogamy was observed in PRO1, BAB1, AGV2, NAV2, IBI2, BAR2 and BAB2. The deficit of heterozygotes at one or more loci and losses of alleles might indicate the presence of null alleles (AUNG et al., 2010), the Wahlund effect, or both (HATANAKA et al., 2006), or the bottleneck effect (GONZÁLEZ-WANGUEMERT et al., 2012). The Wahlund effect did not promote endogamy because the samples were collected in geographically separate locations. However, the analysis from the Micro-Checker program indicated the presence of null alleles in BAB1, AGV2, NAV2, IBI2, BAR2 and $\mathrm{BAB} 2$, in addition to mutation disequilibrium and drift because of the recent bottleneck effect. Thus, the lower average Ho and positive FIS values (endogamy) from BAB1, AGV2, NAV2, IBI2, BAR2 and BAB2 were effectively caused by null alleles in conjunction with the bottleneck effect.

\section{Genetic structure}

Similar to the analysis for the presence and distribution of alleles, the values of GD and GI emphasized the genetic differences among the WPs in both years according to the AMOVA (FST $=0.3403)$, FST, and Nm values for all population combinations. The dendrogram emphasized three clusters: WPs2011, WPs2012 and BS. There are no studies using microsatellites markers of Piaractus mesopotamicus in the current sampling locations to scientifically compare the results. Only one study from Almeida et al. (2003) using Pimelodus maculatus populations from the upper, middle and lower Tietê River (applying RAPD) indicated genetic similarities in those populations (through genetic diversity, gene flow and genetic identity) based on fish transposition by locks built to navigate through the BAB, BAR, IBI, PRO and NAV (the Tietê-Paraná hydro way) hydroelectric power plants.

Analyzing the downstream, middle and upstream WPs of Prochilodus costatus in the Gafanhoto and Cajuru dam reservoirs on the Pará River - Brazil (built in 1940), Barroca et al. (2012) observed genetic differences at both locations, which might be explained by the impeded migration from the dams, restocking (since 1983), river extension, or a combination of all these factors. Thus, based on the differences among the current WPs (AGV, NAV, IBI, PRO, BAB and BAR), some aspects require analysis. First, the Grande River is a tributary of the Parana River, where the watercourse from the Tietê River is located. Thus, ecological, environment and geographical factors may have united between the Tietê and Grande rivers. Piaractus mesopotamicus migrates long distances (MAKRAKIS et al., 2007), 
which would allow gene flow among the WPs of the Grande and Tietê rivers. Thus, genetic differences among the AGV (Grande River) and NAV, IBI, PRO, BAB and BAR (Tietê River) locations are based on habitat fragmentation by the dams in the Hydroelectric Power Plants. After building the HPP (more than 30 years ago) on the evaluated rivers (Grande River = eight HPP - Peixoto, Estreito, Jaguara, Igarapava, Volta Grande, Porto Colômbia, Morimbondo and Agua Vermelha; Tietê River = five HPP - Nova Avanhandava, Barra Bonita, Bariri, Ibitinga and Promissão), the natural gene flow was blocked, even with the hydro link among the HPP on the Tietê River (BAB, BAR, IBI, PRO and NAV) using the Tietê-Paraná hydro way. Thus, subpopulations may have been clustered into new groups of different genetic pools in every water reservoir. Contextually, Esguícero and Arcifa (2010) analyzed the morphologic characteristics of Salminus hilarii up- and downstream of the Gavião Peixoto dam (built in 1913) on the JacaréGuaçu River in Brazil and reported interpolated fragmentation and structures similar to the results of the current study. Similarly, Yamamoto et al. (2004) evaluated the genetic differences of eleven WPs of Salvelinus leucomaenis in Japanese rivers, also affected by dams. These authors observed genetic differences in all WP combinations, and the reduction in genetic variability was proportional to the time of isolation.

In $\mathrm{BSA}, \mathrm{BSB}, \mathrm{BSC}$ and $\mathrm{BSJ}$, there were genetic similarities from the analysis for allele distribution, the AMOVA (0.0287), and GD and GI and FST and $\mathrm{Nm}$ values for all population combinations, which were clustered into one genetic group. These results were expected because the broodstocks were formed from the identical ancestral, from the Paraná River (foundation effect), and identical individuals were introduced from the Tietê and Grande rivers. Additional factors, such as the raising system (i.e., a small group of broodstocks, sexual proportions, reproductive dominance, endogamy, high variations among individuals during reproduction) and fluctuation in population size over time, can also be influenced by the homogeneity of current broodstocks (CAMERON-BROWN et al., 2005; BORREL et al., 2007; FOPP-BAYAT et al., 2010; LOPERA-BARRERO et al., 2010b; POVH et al., 2010).

Finally, studies have concluded that properly conducting restocking programs can effectively increase the number of individuals in WPs (LOPERA-BARRERO et al., 2010a; BARROCA et al., 2012; BLANCO GONZALEZ et al., 2009). In the current study, using the population parameters analyzed, there was no genetic relationship between the WPs and BSs. However, four alleles were shared with the 2012 WPs (Pme4: 95 and 100 bp; Pme14: 95 and $105 \mathrm{bp}$ ). Most likely, the sampling efforts in the WPs were not representative of the total gene pool. Therefore, the presence of alleles, even a few, showed individuals in the WPs from the restocking programs.

\section{Genetic conservation}

The pros and cons of the restocking programs as a preservation methodology of WPs have been recently debated. Negative effects were reported by Marie et al. (2010) who studied the restocking effect on the diversity standard and genetic structure of WPs of Salvelinus fontinalis. These authors observed genetic diversity losses related to the intensity of restocking. Similarly, Satake and Araki (2012), using a population dynamic model, observed a homogeneity event and reduction in the WPs after three generations of restocking. By contrast, Araki and Schmid (2010) surveyed publications from the last 50 years and observed negative and positive effects, which depended on the restocking objective, species, and specifically, the region. Thus, the efficiency of restocking, based on Ward (2006), depends on the use of broodstocks from the identical environment where the restocking and many genitors will occur. An in-depth understanding of the ecology and monitoring of the released stocks 
is important to emphasize the biological and genetic potential to affect WPs (GARDNER et al., 2010).

Furthermore, the precise use of restocking programs also depends on a genetic analysis of the BSs and WPs. The establishment of broodstocks for restocking programs requires a genetic variability analysis because it determines the best genetic pool from the WPs (BORREL et al., 2007), offers an important base to formulate reproductive strategies (LOPERA-BARRERO, 2009) and minimizes adaptation to captivity (WILLIAMS; HOFFMAN, 2009). The use of related individuals reduces the effective size of the population and endogamic depression (GONZÁLEZ-WANGUEMERT et al., 2012). A genetic analysis of WPs is also necessary. The genetic diversity of WPs supplies wild material to maintain species diversity and evolution capacity, which allows adaptation to environmental changes (SANFORD; KELLY, 2011). Thus, it is important to know and preserve genetic diversity.

\section{Conclusions}

In conclusion, adequate genetic variability was observed in the WPs and BSs. The WPs collected in 2011 and 2012 were different and likely affected by the Wahlund effect. Genetic differences were observed among WPs and BSs, but four exclusive alleles in the broodstocks were detected in 2012 , which showed a partial presence of individuals from the restocking program. More studies are required to verify whether the released juveniles adapted and gathered into new populations, which contributed to genes in the next generations. In fact, genetic monitoring using molecular markers in progenitors, progenies and wild populations is fundamental to maintain genetic variability and prevent its effects in population structures. Thus, the use of microsatellite markers was successful in the current project.

\section{Acknowledgements}

We are grateful to the ANNEL and AES Tietê Company for supporting this experiment.

\section{References}

Agostinho, A. A.; PELICICE, F. M.; GOMES, L. C. Dams and the fish fauna of the Neotropical region: impacts and management related to diversity and fisheries. Brazilian Journal of Biology, São Carlos, v. 68, n. 4, p. 1119-1132, 2008.

AgOstinho, A. A.; THOMAZ, S. M.; GOMES, L. C. Conservation of the biodiversity of Brazil's inland waters. Conservation Biology, Boston, v. 19, n. 3, p. 646652, 2005.

Agostinho, C. S.; AgOstinho, A. A.; PELICICE, F.; ALMEIDA, D. A.; MARQUES, E. E. Selectivity of fish ladders: a bottleneck in Neotropical fish movement. Neotropical Ichthyology, Porto Alegre, v. 5, n. 2, p. 205213, 2007.

ALMEIDA, F. S.; SODRÉ, L. M. K.; CONTEL, E. P. B. Population structure analysis of Pimelodus maculatus (Pisces, Siluriformes) from the Tietê and Paranapanema Rivers (Brazil). Genetic and Molecular Biology, São Paulo, v. 26, n. 3, p. 301-305, 2003.

ARAKI, H.; SCHMIT, C. Is hatchery stocking a help or harm? Evidence, limitations and future directions in ecological and genetic surveys. Aquaculture, Amsterdam, v. 308, n. 1, p. 2-11, 2010.

AUNG, O.; NGUYEN, T. T. T.; POOMPUANG, S.; KAMONRAT, W. Microsatellite DNA markers revealed genetic population structure among captive stocks and wild populations of mrigal, Cirrhinus cirrhosus in Myanmar. Aquaculture, Amsterdam, v. 299, n. 1-4, p. 37 43, 2010.

BARROCA, T. M.; SANTOS, G. B.; DUARTE, N. V. R.; KALAPOTHAKIS, E. Evaluation of genetic diversity and population structure in a commercially important freshwater fish Prochilodus costatus (Characiformes, Prochilodontidae) using complex hypervariable repeats. Genetic and Molecular Research, Ribeirão Preto, v. 11, n. 4, p. 4456-4467, 2012.

BASSAM, B. J.; CAETANO-ANOLLÉS, G.; GRESSHOFF, P. M. Fast and sensitive silver staining of DNA in polyacrylamide gels. Analytical Biochemistry, New York, v. 196, n. 1, p. 80-83, 1991.

BLANCO GONZALEZ, E.; MURAKAMI, T.; YUNEJI, T.; NAGASAWA, K.; UMINO, T. Reduction in sizeat-age of black sea bream (Acanthopagrus schlegelii) following intensive releases of cultured juveniles in Hiroshima Bay, Japan. Fisheries Research, Amsterdam, v. 99, n. 2, p. 130-133, 2009.

BORREL, Y. J.; CARLEOS, C. E.; ASTURIANO, J. F.; BERNARDO, D.; VÁZQUEZ, E.; CORRAL, N.; SÁNCHEZ, J. A.; BLANCO, G. Use of microsatellites 
and a combinatorial optimization approach in the acquisition of gilthead seabream (Sparus aurata L.) broodstocks for hatcheries. Aquaculture, Amsterdam, v. 269, n. 1-4, p. 200-210, 2007.

BUCKUP, P. A; MENEZES, N. A; GHAZZI, M. S. Book of freshwater fish species in Brazil. Rio de Janeiro: Museu Nacional, 2007. 160 p.

CABALLERO, A.; RODRÍGUEZ-RAMILO, S. T.; ÁVILA, V.; FERNÁNDEZ, J. Management of genetic diversity of subdivided populations in conservation programmes. Conservation Genetics, Dordrecht, v. 11, n. 2, p. 409-419, 2010.

CALCAGNOTTO, D.; DESALLE, R. Population genetic structuring in pacu (Piaractus mesopotamicus) across the Paraná-Paraguay basin: evidence from microsatellites. Neotropical Ichthyology, Porto Alegre, v. 7, n. 4, p. 607616, 2009.

CAlCAGNOTTO, D.; RUSSELlO, M.; DESALLE, R. Isolation and characterization of microsatellite loci in Piaractus mesopotamicus and their applicability in other Serrasalminae fish. Molecular Ecology Notes, Oxford, v. 1, n. 4, p. 245-247, 2001.

CAMERON-BROWN, R.; WOOLLIAMS, J. A.; MCANDREW, B. J. Factors influencing effective population size in commercial populations of gilthead seabream, Sparus aurata. Aquaculture, Amsterdam, v. 247, n. 1-4, p. 219-225, 2005.

CARVALHO-COSTA, L. F.; HATANAKA, T.; GALETTI JÚNIOR, P. M. Evidence of lack of population substructuring in the Brazilian freshwater fish Prochilodus costatus. Genetics and Molecular Biology, Ribeirão Preto, v. 31, n. 1, p. 377-380, 2008.

CORNUET, J. M.; LUIKART, G. Description and power analysis of two tests for detecting recent population bottlenecks from allele frequency data. Genetics, Bethesda, v. 144, n. 4, p. 2001-2014, 1996.

DEHAIS, C.; EUDELINE, R.; BERREBI, P.; ARGILLIER, C. Microgeographic genetic isolation in chub (Cyprinidae: Squalius cephalus) population of the Durance River: estimating fragmentation by dams. Ecology of Freshwater Fish, Copenhagen, v. 19, n. 2, p. 267-278, 2010.

ESGUÍCERO, A. L. H.; ARCIFA, M. S. Fragmentation of a Neotropical migratory fish population by a centuryold dam. Hydrobiologia, Den Haag, v. 638, n. 1, p. 41-53, 2010 .

EXCOFFIER, L.; LAVAL, G.; SCHNEIDER, S. Arlequin ver. 3. 0: an integrated software package for population genetics data analysis. Evolutionary Bioinformatics Online, Auckland, v. 1, n. 1, p. 47-50, 2005.
FALCONER, D. S. Introduction to quantitative genetics. $3^{\text {th }}$ ed. New York: Longman, 1989. 361 p.

FOPP-BAYAT, D. Microsatellite DNA variation in the Siberian sturgeon, Acipenser baeri (Actinopterygii, Acipenseriformes, Acipenseridae), cultured in a Polish fish farm. Acta Ichthyologica et Piscatoria, Szczecin, v. 40, n. 1, p. 21-25, 2010.

FOPP-BAYAT, D.; JANKUN, M.; KUZMINSKI, H. Genetic characterization of Polish cultured brook trout, Salvelinus fontinalis (Mitchill), based on microsatellite DNA analysis. Archives of Polish Fisheries, Olsztyn, v. 18, n. 2, p. 93-99, 2010.

GARCEZ, R.; CALCAGNOTTO, D.; ALMEIDATOLEDO, L. F. Population structure of the migratory fish Prochilodus lineatus (Characiformes) from rio Grande basin (Brazil), an area fragmented by dams. Aquatic Conservation, Chichister, v. 21, n. 3, p. 268-275, 2011.

GARDNER, M. J.; COTTINGHAM, A.; PHILLIPS, N. M.; HESP, S. A.; CHAPLIN, J. A.; JENKINS, G. I. Biological performance and genetics of restocked and wild Black Bream in the Blackwood river estuary. Report to the West Australian Fish Foundation. Sidney: Project Funded by the Department of Fisheries, 2010. 57 p.

GONZÁLEZ-WANGUEMERT, M.; FERNÁNDEZ, T. V.; PÉREZ-RUZAFA, A.; GIACALONE, M.; D'ANNA, G.; BADALAMENTI, F. Genetic considerations on the introduction of farmed fish in marine protected areas: The case of study of white seabream restocking in the Gulf of Castellammare (Southern Tyrrhenian Sea). Journal of Sea Research, Den Burg, v. 68, n. 1, p. 41-48, 2012.

GOUDET, J. FSTAT: a program to estimate and test gene diversities and fixation indices (version 2. 9. 3. 2). Lausanne: Department of Ecology and Evolution, 2002. Available at: <http://www.unil.ch/izea/softwares/fstat. html>. Acessed at: 13 jan 2014.

HATANAKA, T.; HENRIQUE-SILVA, F.; GALETTI JÚNIOR, P. M. Population substructuring in a migratory freshwater fish Prochilodus argenteus (Characiformes, Prochilodontidae) from the São Francisco River. Genetica, Dordrecht, v. 126, n. 1-2, p. 153-159, 2006.

HORNE, J. B.; MONIGLIANO, P.; HERWERDEN, L. V.; NEWMAN, S. J. Murky waters: searching for structure in genetically depauperate blue thread fin populations of Western Australia. Fisheries Research, Amsterdam, v. 146, n. 1, p. 1-6, 2013.

HULAK, M.; KASPAR, V.; KOHLMANN, K.; COWARD, K.; TESITEL, J.; RODINA, M.; GELA, D.; KOCOUR, M.; LINHART, O. Microsatellite-based genetic diversity and differentiation of foreign common carp (Cyprinus carpio) strains farmed in the Czech 
Republic. Aquaculture, Amsterdam, v. 298, n. 3-4, p. 194-201, 2010.

LOPERA-BARRERO, N. M. Conservation of Brycon orbignyanus natural populations and stocks for their reproductive, genetic, environmental sustainability: A model for species threatened with extinction. Ciencia e Investigacion Agraria, Santiago, v. 36, n. 2, p. 191-208, 2009.

LOPERA-BARRERO, N. M.; RIBEIRO, R. P.; POVH, J. A.; SIROL, R. N.; MANGOLIN, C. A. Genetic evaluation of pacu (Piaractus mesopotamicus) natural populations and from the broodstocks of a stock enhancement program using microsatellite markers. Arquivo Brasileiro de Medicina Veterinária e Zootecnia, Belo Horizonte, v. 62, n. 4, p. 954-963, 2010a.

LOPERA-BARRERO, N. M.; RODRIGUEZRODRIGUEZ, M. del P.; RIBEIRO, R. P.; POVH, J. A.; VARGAS, L.; STREIT JÚNIOR, D. P.; FORNARI, D. C. Reproductive contribution of a Brycon orbignyanus (Cuvier and Valenciennes, 1850) offspring in the seminatural reproductive system using microsatellite markers. Zootecnia Tropical, Maracay, v. 28, n. 3, p. 403-411, $2010 \mathrm{~b}$.

LOPERA-BARRERO, N. M.; POVH, J. A.; RIBEIRO, R. P.; GOMES, P. C.; JACOMETO, C. B.; LOPES, T. S. Comparison of DNA extraction protocols of fish fin and larvae samples: modified salt $(\mathrm{NaCl})$ extraction. Ciencia e Investigacion Agraria, Santiago, v. 35, n. 1, p. 65-74, 2008.

MAKRAKIS, M. C.; MIRANDA, L. E.; MAKRAKIS, S.; XAVIER, M. M.; FONTES, H. M.; MORLIS, W. G. Migratory movements of pacu, Piaractus mesopotamicus, in the highly impounded Parana River. Journal of Applied Ichthyology, Hamburg, v. 23, n. 6, p. 700-704, 2007.

MARCENIUK, A. P.; HILSDORF, A. W. S.; LANGEANI, F. The ichthyofauna from the headwaters of the rio Tietê, São Paulo, Brazil. Biota Neotropica, São Paulo, v. 11, n. 3, p. 217-236, 2011.

MARIE, A. D.; BERNATCHEZ, L.; GARANT, D. Loss of genetic integrity correlates with stocking intensity in brook charr (Salvelinus fontinalis). Molecular Ecology, Oxford, v. 19, n. 10, p. 2025-2037, 2010.

MERANER, A.; GRATTON, P.; BARALDI, F.; GANDOLFI, A. Nothing but a trace left? Autochthony and conservation status of Northern Adriatic Salmo trutta inferred from PCR multiplexing, mtDNA control region sequencing and microsatellite analysis. Hydrobiologia, Den Haag, v. 702, n. 1, p. 201-213, 2013.
MU, X. D.; HU, Y. C.; WANG, X. J.; SONG, H. M.; YANG, Y. X.; LUO, J. R. Genetic variability in cultured stocks of Scleropages formosus in Mailand China revealed by microsatellite markers. Journal of Animal and Veterinary Advances, Faisalabad, v. 10, n. 5, p. 555$561,2011$.

NA-NAKORN, U.; MOEIKUM, T. Genetic diversity of domesticated stocks of striped catfish, Pangasianodon hypophthalmus (Sauvage 1878), in Thailand: relevance to broodstock management regimes. Aquaculture, Amsterdam, v. 297, n. 1-4, p. 70-77, 2009.

NEI, M. Estimation of average heterozygosity and genetic distance from a small number of individuals. Genetics, Bethesda, v. 89, n. 3, p. 583-590, 1978.

NOLAN, D. V.; POWELL, R. Geographic and temporal genetic structure in Lepeophtheirus salmonis from four salmon farms along the northwest and west coasts of Ireland: results from a microsatellite analysis. Hydrobiologia, Den Haag, v. 617, n. 1, p. 55-63, 2009.

O'CONNELL, M.; WRIGHT, J. M. Microsatellite DNA in fishes. Reviews in Fish Biology and Fisheries, London, v. 7, n. 3, p. 331-363, 1997.

POVH, J. A.; RIBEIRO, R. P.; LOPERA BARRERO, N. M.; JACOMETO, C. B.; VARGAS, L.; GOMES, P. C.; LOPES, T. S. Microsatellite analysis of pacu broodstocks used in the stocking program of Paranapanema river, Brazil. Scientia Agricola, Piracicaba, v. 68, n. 3, p. 308313, 2011.

POVH, J. A.; RIBEIRO, R. P.; SIROL, R. N.; STREIT JÚNIOR, D. P.; MOREIRA, H. L. M.; SIEWERDT, F.; LOPERA BARRERO, N. M.; MANGOLIN, C. A.; VARGAS, L. Microsatellite analysis of the parental contribution of Piaractus mesopotamicus to the production of offspring in the semi-natural system of reproduction. Brazilian Archives of Biology and Technology, Curitiba, v. 53, n. 2, p. 389-396, 2010.

RESENDE, E. K. Migratory fishes of the ParaguayParaná Basin excluding the upper Paraná River. In: CAROLSFELD, J.; ROSS, B. H. C.; BAER, A. (Ed.). Migratory fishes of South America: biology, fisheries, and conservation status. Victoria: World Fisheries Trust/ IDRC/World Bank, 2003. p. 99-155.

RIBOLLI, J.; MELO, C. M. R.; ZANIBONY-FILHO, E. Genetic characterization of the Neotropical catfish Pimelodus maculatus (Pimelodidae, Siluriformes) in the Upper Uruguay River. Genetics and Molecular Biology, Ribeirão Preto, v. 35, n. 4, p. 761-769, 2012.

RICE, W. R. Analyzing table of statistical tests. Evolution, New York, v. 43, n. 1, p. 223-225, 1989. 
ROUSSET, F. Genepop 2007: a complete reimplementation of the GENEPOP software for Windows and Linux. Molecular Ecology Resources, Oxford, v. 8, n. 1, p. 103-106, 2008.

SANFORD, E.; KELLY, W. Local adaptation in marine invertebrates. Annual Review of Marine Science, Palo Alto, v. 3, n. 1, p. 509-535, 2011.

SATAKE, A.; ARAKI, H. Stocking of captive-bred fish can cause long-term population decline and gene pool replacement: predictions from a population dynamics model incorporating density-dependent mortality. Theoretical Ecology, Amsterdam, v. 5, n. 2, p. 283-296, 2012.

TAMURA, K.; PETERSON, D.; PETERSON, N.; STECHER, G.; NEI, M.; KUMAR, S. MEGA5: Molecular evolutionary genetics analysis using maximum likelihood, evolutionary distance, and maximum parsimony methods. Molecular Biology and Evolution, Chicago, v. 28, n. 10, p. 2731-2739, 2011.

VAN OOSTERHOUT, C; HUTCHINSON, W. F. D.; WILLS, P. M.; SHIPLEY, P. Micro-Checker: software for identifying and correcting genotyping errors in microsatellite data. Molecular Ecology Notes, Oxford, v. 4, n. 3, p. 535-538, 2004.

WARD, R. D. The importance of identifying spatial population structure in restocking and stock enhancement programmes. Fisheries Research, Amsterdam, v. 80, n. 1, p. 9-18, 2006.
WEIR, B. S.; COCKERHAM, C. C. Estimating F-statistics for the analysis of population structure. Evolution, New York, v. 38, n. 6, p. 1358-1370, 1984.

WILliAMS, S. E.; HOFFMAN, E. A. Minimizing genetic adaptation in captive breeding programs: a review. Biological Conservation, Barking, v. 142, n. 11, p. 2388-2400, 2009.

WILSON, A. J.; GÍSLASON, D.; SKÚLASON, S.; SNORRASON, S. S.; ADAMS, C. E.; ALEXANDER, G.; DANZMANN, R. G.; FERGUSON, M. M. Population genetic structure of Arctic Charr, Salvelinus alpinus from northwest Europe on large and small spatial scales. Molecular Ecology, Oxford, v. 13, n. 5, p. 1129$1142,2004$.

WRIGHT, S. Evolution and genetics of population. Chicago: University of Chicago Press, 1978. 590 p.

YAMAMOTO, S.; MORITA, K.; KOIZUMI, I.; MAEKAWA, K. Genetic differentiation of whitespotted charr (Salvelinus leucomaenis) populations after habitat fragmentation: Spatial-temporal changes in gene frequencies. Conservation Genetics, Dordrecht, v. 5, n. 4, p. 529-538, 2004.

YEH, F. C.; BOYLE, T. Y. Z.; XIYAN, J. M. PopGene Version 131: Microsoft Window-based freeware for population genetic analysis. Alberta: University of Alberta and Center for International Forestry Research, 1999. 28 p. 
